\title{
A Honeycomb-Shaped Brass Plate Catalyst to Reduce Motor Vehicle Emissions
}

\author{
Ali Mokhtara ${ }^{\mathrm{a}}$, Ali Saifullah ${ }^{\mathrm{b}}$, Andinusa Rahmandhika ${ }^{\mathrm{c}}$ \\ a,b,c Mechanical Engineering Department, Faculty of Engineering, Muhammadiyah Malang University \\ Jl. Raya Tlogomas No. 246 Malang \\ Telp. 0811360358, Email alimokhtar011@gmail.com, mokhtar@umm.ac.id
}

\begin{abstract}
The increasing number of motorized vehicles has a direct impact on exhaust gas air pollution. The air pollution in urban areas is dominated by motorized vehicle emissions, along with pollution problems. This study aims to reduce motor vehicle emissions by using a catalytic converter design made from a brass plate catalyst in the shape of a honeycomb. Honeycomb-shaped brass is suitable for catalysts in the catalytic converter. Besides being easy to obtain and cheap in price, the catalyst can reduce and oxidize exhaust gases well, making it suitable as a catalyst material. The method used in this research is the experimental method. It is started from the design of the catalytic converter house and determining the type of catalyst to the process of making the catalytic converter with a honeycomb-shaped brass plate. Then, testing to determine the emission of exhaust gases produced is required. The last step is to compare it without using a catalytic converter or standard conditions. From the results of the emission test, it was found that the use of a catalytic converter made from a brass plate catalyst in the shape of a honeycomb can reduce $\mathrm{HC}$ and $\mathrm{CO}$ emissions, while $\mathrm{CO} 2$ emissions has increased. A decrease in $\mathrm{HC}$ gas emissions by $19.1 \%$ for a single catalytic converter and $33.7 \%$ for a dual catalytic converter are better compared to without using a catalytic converter or standard conditions. Reduced CO gas emissions by $23.8 \%$ for a single catalytic converter and $43.1 \%$ for a dual catalytic converter are compared to without using a catalytic converter. Meanwhile, CO2 gas emissions increased by $60.7 \%$ for a single catalytic converter, and $81.6 \%$ for multiple catalytic converters are compared without using a catalytic converter. This is a result of the addition of oxygen to the oxidation process that running smoothly.
\end{abstract}

Keywords: honeycomb-shaped brass plate, catalytic converter, emission

\section{INTRODUCTION}

The catalytic converter is an exhaust emission control device installed in motorized vehicles [1]. The phenomenon of gas flow in the catalytic converter channel is difficult to observe, but it can be analyzed using FLUENT or ANSYS software. Simulations can be performed to determine the flow patterns that are formed in the channel. The more evenly the exhaust gas on the surface of the catalytic converter, the greater the emission reduction process [2]-[5]. The increase in the number of motorized vehicles will increase the use of fuel oil, especially in two-stroke engine vehicles, where the combustion process in these vehicles cannot be perfect compared to four-stroke engine vehicles. This will bring risks to the addition of toxic gases in the air, especially $\mathrm{CO}, \mathrm{HC}, \mathrm{SO} 2$ [6],[7].

Catalytic converters have become standard equipment for all motorized vehicles in the world. The catalyst will work effectively if the smoke gas can hit all surfaces of the catalyst and work between temperatures of $250^{\circ} \mathrm{C}$ to $300^{\circ} \mathrm{C}$ [8],[9]. The flow of flue gas through the horizontal hole catalyst without insulation shows good flow distribution results [8],[9]. Catalytic converter with aluminum catalyst shows poor results to reduce emissions 
[10]. Therefore, from the advantages and disadvantages of previous research, the present work was carried out by making a catalytic converter with a beehive-shaped brass plate as a catalyst.

The problem in this study is how much emission levels are produced by motorized vehicles if they do not use a catalytic converter or in standard conditions. This value is then compared with the catalytic converter with a catalyst material from a honeycombshaped brass plate.

The purpose of this study was to determine how much emissions a motorized vehicle would produce if it did not use a catalytic converter or standard conditions compared to using a catalytic converter with a catalyst material from a honeycombshaped brass plate, both single and multiple types. The honeycomb catalyst design model is as follows.
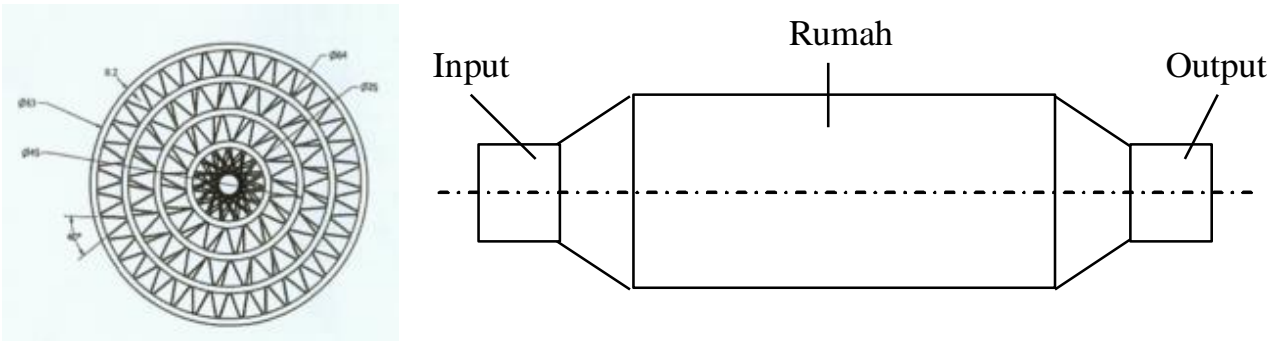

Figure 1. Honeycomb catalyst design

Incomplete combustion results in the formation of pollutant gas emissions such as $\mathrm{HC}, \mathrm{CO}, \mathrm{NOx}$ which are released by motor vehicles. In fact, there is no way that combustion can be 100\% complete. Therefore, the catalytic converter needs to be installed in all motorized vehicles. The catalytic reduction reaction is principally to increase the reactance site of NO molecules (as in nickel or copper in CO) to form N2 and $\mathrm{CO} 2$ gases. NO can react with metal molecules to form oxides which then react with $\mathrm{CO}$. Meanwhile, metal molecules that can be used as reducing catalysts are iron, nickel, copper, alloys, and oxides of these metals [11]-[13].

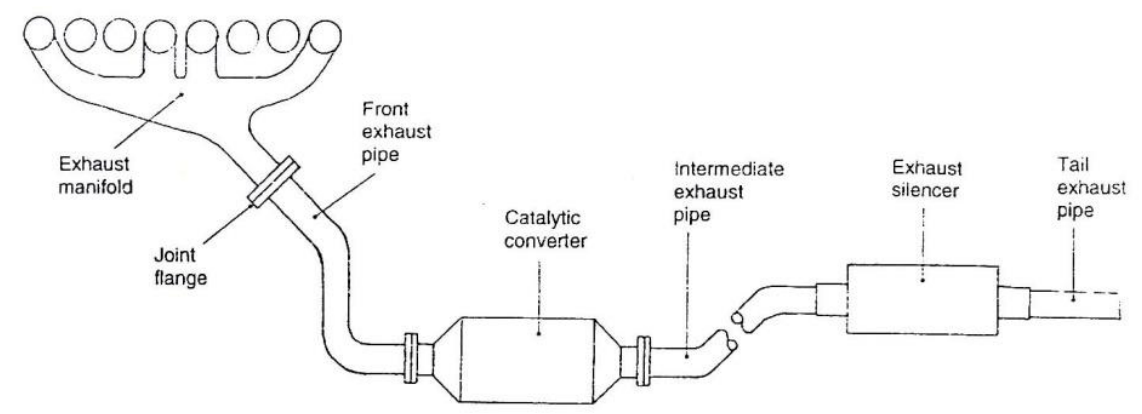

Figure 2. Exhaust gas design with Catalytic Converter (Heisler H, 1999)

\section{Methods}

A catalytic Converter (CC) is a tool to accelerate the combustion process of residual hydrocarbons $(\mathrm{HC})$, carbon monoxide (CO), and nitrogen oxidation (NOx) which are still present in motor vehicle exhaust gases. When passing through the catalytic converter, the gas will undergo a chemical process (oxidized and reduced) due to the addition of oxygen and high temperatures. The combustion process of remaining hydrocarbons $(\mathrm{HC})$, carbon monoxide ( $\mathrm{CO})$, and nitrogen oxides (NOx) which is still present in the exhaust gas when it passes through the catalyst will turn into stable compounds in the form of $\mathrm{CO} 2, \mathrm{H} 2 \mathrm{O}$, N2, and $\mathrm{O} 2[14],[15]$. 


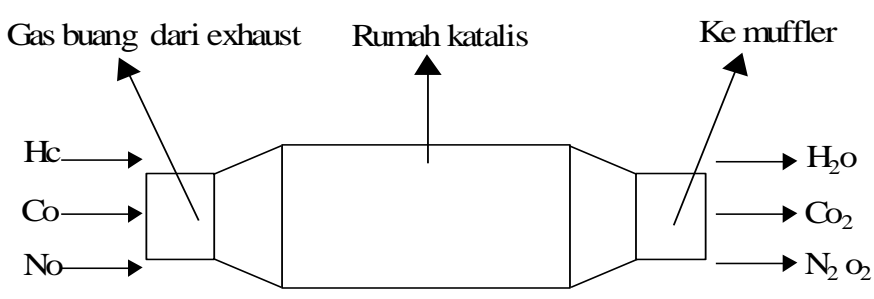

Figure 3. Catalytic converter design model

Exhaust gas emissions in the form of hazardous chemicals will be converted into harmless chemicals using a catalytic converter in the exhaust gas line [16], [17]. Among the catalysts used as catalytic converters, metals are the most effective materials as oxidation catalysts, including platinum, plutonium, palladium, copper, vanadium, iron, cobalt, nickel, manganese, chromium, and oxides of these metals [13]. The process of designing a catalyst in a catalytic converter requires special care to get maximum results, especially when the gas flow occurs in the catalyst. The more evenly the gas flow in the catalyst, the more optimal the reduction process will be so that the emissions released are reduced [2].
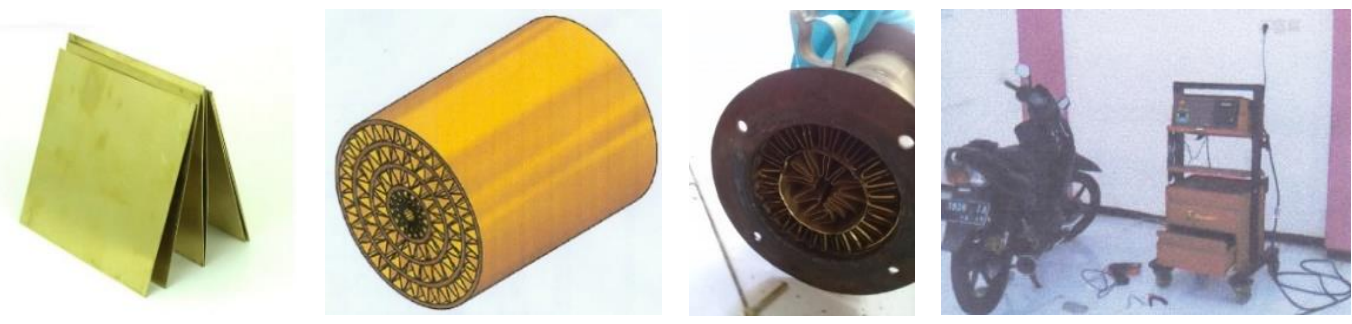

Figure 4. Materials, Assemblies, Testing Machines and Gas Analyzers

Table 1. Experimental variable

\begin{tabular}{ccccccc}
\hline $\begin{array}{c}\text { Catalytic } \\
\text { Converter }\end{array}$ & Fuel & $\mathbf{1 0 0 0}$ & $\mathbf{1 5 0 0}$ & $\mathbf{2 0 0 0}$ & $\mathbf{2 5 0 0}$ & \multirow{2}{*}{$\mathbf{3 5 0 0}$} \\
\hline Standard & Pertalite & D111 & D121 & D131 & D141 & D151 \\
& & D112 & D122 & D132 & D142 & D152 \\
& & D113 & D123 & D133 & D143 & D153 \\
& & D114 & D124 & D134 & D144 & D154 \\
& D115 & D125 & D135 & D145 & D155 \\
Single CC & Pertalite & D211 & D221 & D231 & D241 & D251 \\
& & D212 & D222 & D232 & D242 & D252 \\
& & D213 & D223 & D233 & D243 & D253 \\
& & D214 & D224 & D234 & D244 & D254 \\
& D215 & D225 & D235 & D245 & D255 \\
Double CC & Pertalite & D311 & D321 & D331 & D341 & D351 \\
& & D312 & D322 & D332 & D342 & D352 \\
& & D313 & D323 & D333 & D343 & D353 \\
& D314 & D324 & D334 & D344 & D354 \\
& & D315 & D325 & D335 & D345 & D355 \\
\hline
\end{tabular}


The research method used is the experimental method. The first step is to conduct a motor vehicle emission test without using an ordinary catalytic converter, then conduct a motor vehicle emission test. The same step is carried out for the catalytic converter made of catalyst from a honeycomb-shaped brass plate. This catalyst has been recommended in previous studies. The design process is carried out before making the catalyst shape. The results of the catalyst molding are then tested for precision with the existing exhaust designs. The principle of this precision test is to show that the catalyst design is suitable for the exhaust shape that has been used. The final stage after a successful precision test is the installation of the latest catalyst model on the vehicle and testing its emissions. Emission testing is performed using an emission measuring device in the form of a gas analyzer. This tool serves to measure the level of exhaust gas emissions by inserting a gas detector pipe into the exhaust hole. The pipe will absorb the remaining combustion gas which is then read in the form of an analog value which shows the amount of emission content of the gas. The emission value is then printed out as desired.

The initial way of making a catalyst is to cut the brass plate according to size, then assemble it according to the predetermined distance between the plates. Then, the whole assembly process is carried out using a welding machine as shown in Figure 4.

\section{Result AND Discussion}

From the test results obtained preliminary data for standard catalytic converters (shown in Table 2), with a single (Table 3) and double honeycomb-shaped brass plate as a catalyst (Table 4). The percentage of gas emission and reduction is shown in Table 5 and Table 6, respectively.

Table 2. Experimental result of standard model

\begin{tabular}{ccccccc}
\hline $\begin{array}{c}\text { Engine Speed } \\
(\mathbf{r p m})\end{array}$ & Data & $\mathrm{HC}(\mathbf{p p m})$ & $\begin{array}{c}\mathrm{CO} \\
(\%)\end{array}$ & $\begin{array}{c}\mathrm{CO}_{2} \\
(\%)\end{array}$ & $\begin{array}{c}\mathrm{O}_{2} \\
(\%)\end{array}$ & $\mathbf{T}\left({ }^{\circ} \mathbf{C}\right)$ \\
\hline 1000 & Average & 782,8 & 4,16 & 4,96 & 8,43 & 247,22 \\
1500 & Average & 678,2 & 4,28 & 6,12 & 7,83 & 261,4 \\
2000 & Average & 525,8 & 4,54 & 7,12 & 5,58 & 272,94 \\
2500 & Average & 461,4 & 4,72 & 7,92 & 4,916 & 297,48 \\
3500 & Average & 414,2 & 5,12 & 8,8 & 4,604 & 316,1 \\
\hline
\end{tabular}

Table 3. Experimental result of single catalytic converter model

\begin{tabular}{ccccccc}
\hline $\begin{array}{c}\text { Engine Speed } \\
(\mathbf{r p m})\end{array}$ & Data & $\mathbf{H C}(\mathbf{p p m})$ & $\begin{array}{c}\mathbf{C O} \\
(\%)\end{array}$ & $\begin{array}{c}\mathbf{C O}_{2} \\
(\%)\end{array}$ & $\begin{array}{c}\mathbf{O}_{2} \\
(\%)\end{array}$ & $\mathbf{T}\left({ }^{\circ} \mathbf{C}\right)$ \\
\hline 1000 & Average & 625,2 & 3,04 & 9,60 & 6,54 & 266,4 \\
1500 & Average & 557,6 & 3,30 & 10,24 & 5,67 & 286,66 \\
2000 & Average & 425,2 & 3,50 & 11,50 & 4,20 & 302,3 \\
2500 & Average & 375,2 & 3,66 & 12,34 & 3,57 & 318,12 \\
3500 & Average & 332,6 & 3,90 & 12,44 & 3,48 & 338,96 \\
\hline
\end{tabular}

Table 4. Experimental result of double catalytic converter model

\begin{tabular}{ccccccc}
\hline $\begin{array}{c}\text { Engine Speed } \\
(\mathbf{r p m})\end{array}$ & Data & $\mathbf{H C}(\mathbf{p p m})$ & $\begin{array}{c}\mathbf{C O} \\
(\%)\end{array}$ & $\begin{array}{c}\mathbf{C O}_{2} \\
(\%)\end{array}$ & $\begin{array}{c}\mathbf{O}_{2} \\
(\%)\end{array}$ & $\mathbf{T}\left({ }^{\circ} \mathbf{C}\right)$ \\
\hline 1000 & Average & 538,80 & 2,14 & 11,74 & 4,39 & 284,56 \\
1500 & Average & 444,80 & 2,36 & 12,14 & 3,72 & 302,36 \\
2000 & Average & 335,00 & 2,66 & 12,76 & 2,84 & 314,78 \\
2500 & Average & 307,00 & 2,84 & 13,36 & 2,53 & 333,74 \\
3500 & Average & 270,20 & 2,98 & 13,40 & 2,28 & 352,64 \\
\hline
\end{tabular}


JEMMME (Journal of Energy, Mechanical, Material, and Manufacturing Engineering) Vol.6, No. 1, 2021 doi: 10.22219/jemmme.v6i1.15532

Single CC emission percentage $=\frac{(\text { Standard emission }- \text { Single CC emission })}{\text { Standard emission }} \times 100 \%$

Double CC emission percentage $=\frac{\text { Double CC emission }}{\text { Standard emission }} \times 100 \%$

Table 5. Percentage of data emissions

\begin{tabular}{llllll}
\hline CC Type & $\mathbf{H C}(\mathbf{p p m})$ & $\begin{array}{l}\mathbf{C O} \\
\mathbf{( \% )}\end{array}$ & $\begin{array}{l}\mathrm{CO}_{2} \\
(\%)\end{array}$ & $\begin{array}{l}\mathbf{O}_{2} \\
(\%)\end{array}$ & $\mathbf{T}\left({ }^{\circ} \mathbf{C}\right)$ \\
\hline Standard & 572,48 & 4,56 & 6,98 & 6,27 & 279,028 \\
Single CC & 463,16 & 3,48 & 11,22 & 4,69 & 302,488 \\
Double CC & 379,16 & 2,60 & 12,68 & 3,15 & 317,616 \\
Single CC emission percentage & 19,10 & 23,75 & $-60,71$ & 25,20 & $-8,41$ \\
Double CC emission percentage & 33,77 & 43,12 & $-81,56$ & 49,76 & $-13,83$ \\
\hline
\end{tabular}

Reduction of Single CC emission percentage $=100 \%-$ Single CC emission percentage

Reduction of Double CC emission percentage $=100 \%-$

Double CC emission percentage

Table 6. Percentage of emissions reduction

\begin{tabular}{llllll}
\hline CC Type & $\begin{array}{l}\mathbf{H C} \\
(\mathbf{p p m})\end{array}$ & $\begin{array}{l}\mathbf{C O} \\
(\%)\end{array}$ & $\begin{array}{l}\mathrm{CO}_{2} \\
(\%)\end{array}$ & $\begin{array}{l}\mathbf{O}_{2} \\
(\%)\end{array}$ & $\mathbf{T}\left({ }^{\circ} \mathbf{C}\right)$ \\
\hline $\begin{array}{l}\text { \% Reduction of Single CC emission } \\
\text { \% Reduction of Double CC }\end{array}$ & 80,90 & 76,25 & 160,71 & 74,80 & 108,41 \\
emission & 66,23 & 56,88 & 181,56 & 50,24 & 113,83 \\
\hline
\end{tabular}

Data were collected five times in each cycle, then averaged and plotted. The rotation variation is taken between $1000 \mathrm{rpm}$ to $3500 \mathrm{rpm}$. The rotation data is taken with the assumption that the vehicle operates stationary at $1000 \mathrm{rpm}$ and the maximum rotation is $3500 \mathrm{rpm}$.

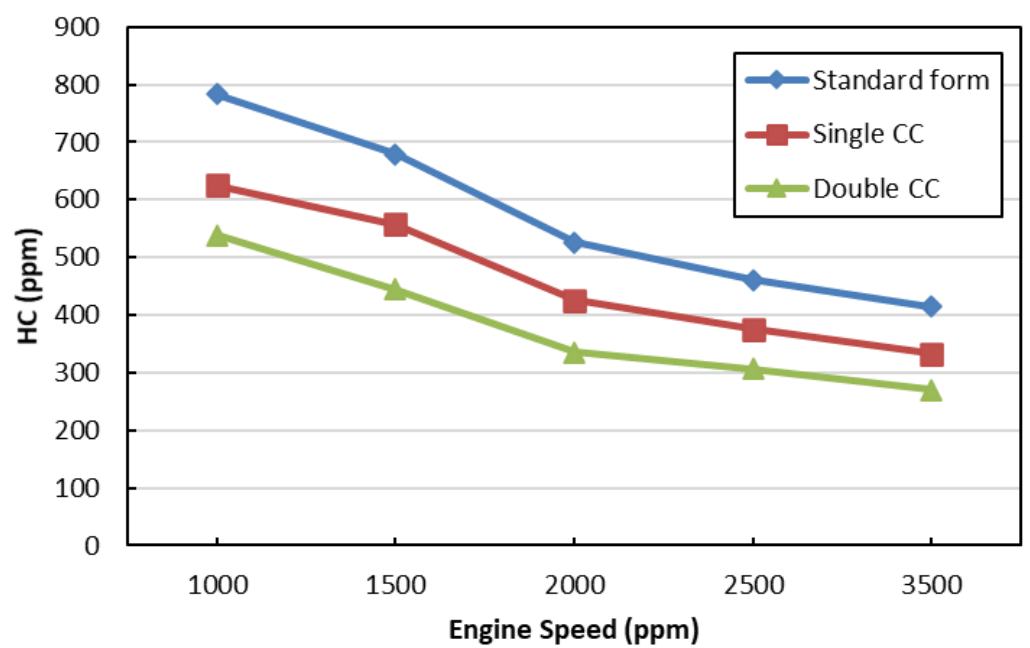

Figure 5. Comparison of $\mathrm{HC}$ emission to engine speed

From the results of the emission test, it can be seen in Figure 5 that the standard model shows a high enough $\mathrm{HC}$ emission level with an average value of $572.48 \mathrm{ppm}$. The 
JEMMME (Journal of Energy, Mechanical, Material, and Manufacturing Engineering)

brass plate model in the form of a single honeycomb has decreased emission levels with an average value of $463.16 \mathrm{ppm}$. While the double honeycomb-shaped brass plate model has decreased with an average value of $379.16 \mathrm{ppm}$. This happens because the smoke gas that comes out through the catalytic converter undergoes a good reduction and oxidation process so that the $\mathrm{HC}$ emissions can decrease. The maximum level of $\mathrm{HC}$ reduction of $33.7 \%$ occurred in a double honeycomb-shaped brass plate catalyst.

Based on the emission test results in Figure 6, it can be seen that the standard model shows a sufficiently large $\mathrm{CO}$ emission level with an average value of $4.56 \%$. The largest decrease occurred in the brass plate model in the form of a single honeycomb with an average value of $3.48 \%$. This happens because the fume gas that comes out through the catalytic converter undergoes a process of reduction and oxidation well so that $\mathrm{CO}$ emissions can decrease. For the double $\mathrm{CC}$, the reduction level is still below the single CC due to in this model there are many obstacles when the exhaust gas comes out of the engine.

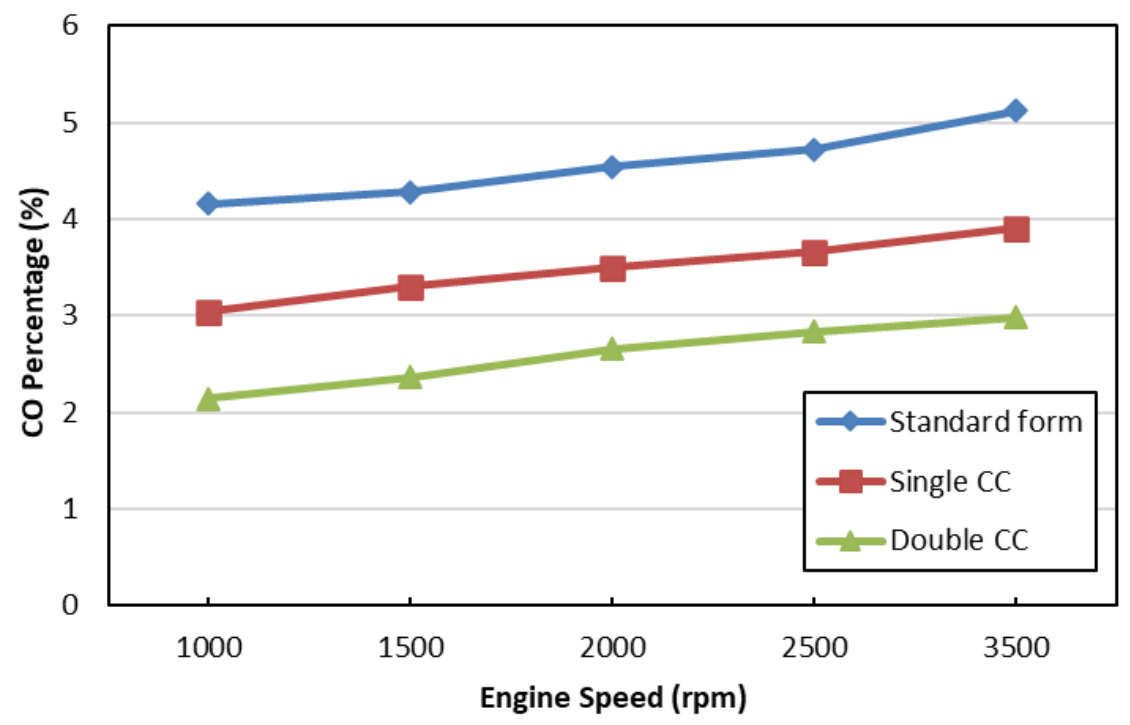

Figure 6. Comparison of $\mathrm{CO}$ emission percentage to engine speed

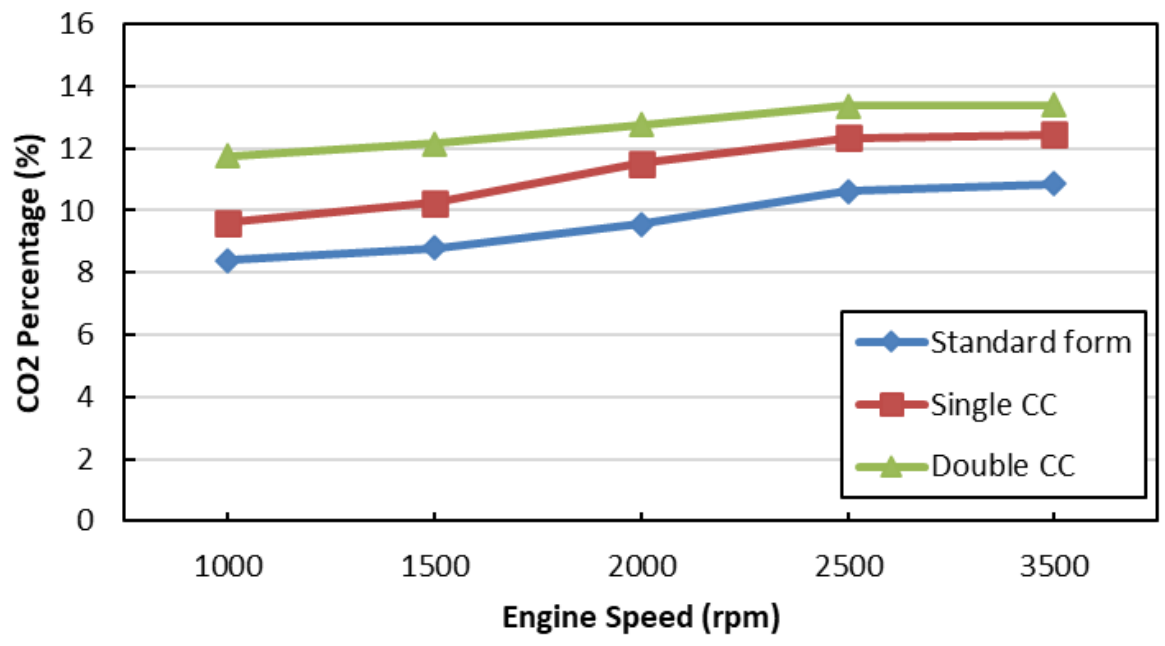

Figure 7. Comparison of $\mathrm{CO}_{2}$ emission percentage to engine speed

From the emission test results in Figure 7, the average value of $\mathrm{CO} 2$ emission levels in the standard model is $6.98 \%$. In the single honeycomb-shaped brass plate model, there is an increase with an average value of $11.22 \%$. Meanwhile, the double 
honeycomb-shaped brass plate model has increased with an average value of $12.68 \%$. This happens because the fume gas that comes out through the catalytic converter undergoes a process of reduction and oxidation well and the process of adding oxygen runs perfectly so that $\mathrm{CO} 2$ emissions can rise. The maximum $\mathrm{CO} 2$ increase level of $81.68 \%$ occurred in a double honeycomb-shaped brass plate catalyst.

\section{Conclusion}

From the results, it can be concluded that the Catalytic Converter with a brass plate catalyst material in the shape of a honeycomb can significantly reduce emissions compared to the standard model or the model without a catalytic converter. The most significant emission reduction occurred for $\mathrm{HC}$ and $\mathrm{CO}$, respectively $33.7 \%$ and $43.12 \%$. Meanwhile, CO2 emissions increased by $81.26 \%$. This is a result of the addition of oxygen to the oxidation process. Meanwhile, in the reduction process, there was a significant reduction in emissions.

\section{REFERENCES}

1. Sharma SK, Goyal P, Tyagi RK. Conversion efficiency of catalytic converter. Int J Ambient Energy. 2016 Sep 2;37(5):507-12. DOI: https://doi.org/10.1080/01430750.2015.1020567

2. Mokhtar A. Catalityc converter jenis katalis plat tembaga berbentuk sarang lebah untuk mengurangi emisi kendaraan bermotor. J Gamma. 2015;(Sudomo):104-8. DOI: https://doi.org/10.22219/sentra.v0i1.1985

3. Mokhtar A, Suprianto H, Yulianto F. Jenis Katalis Kawat Kuningan Berbentuk Sarang Laba-Laba untuk Mengurangi Emisi Kendaraan Bermotor. SENTRA (Seminar Teknol dan Rekayasa). 2017;3. DOI: https://doi.org/10.22219/sentra.v0i3.1417

4. Mokhtar A. Catalityc Converter Jenis Lubang Horizontal untuk Mengurangi Emisi Kendaraan Bermotor. GAMMA. 2010;5(2).

5. Shoffan IAN, Sumarli S, Nauri M. The effect of copper-based catalytic converter with circular tube shape on exhaust emission of Yamaha Vixion 1PA. In: The 2nd International Conference on Green Civil and Environmental Engineering. Malang: IOP Publishing; 2019.

6. Xie C, Toops T, Lance M, Qu J, Viola M, Lewis S, et al. Impact of Lubricant Additives on thePhysicochemical Properties and Activity of Three-Way Catalysts. Catalysts. 2016 Apr 4;6(4):54. DOI: https://doi.org/10.3390/catal6040054

7. Dey S, Mehta NS. Automobile pollution control using catalysis. Resour Environ Sustain. 2020 Dec;2:100006. DOI: https://doi.org/10.1016/j.resenv.2020.100006

8. Mathur ML, Sharma RP. Internal Combustion Engine. 2nd ed. New York: McGrawHill Book Company, Inc; 1975.

9. Bosch R. Emission Control Technology for Gasoline Engines. 3rd ed. German: Stuttgart; 2003.

10. Mokhtar A. Catalityc Converter Jenis Katalis Pipa Tembaga Berlubang untuk Mengurangi Emisi Kendaraan Bermotor Ali Mokhtar. J Gama. 2012;8(September):125-31.

11. Mokhtar A, Wibowo T. Catalityc Converter Jenis Katalis Stainless Steel Berbentuk Sarang Laba-Laba untuk Mengurangi Emisi Kendaraan Bermotor. SENTRA (Seminar Teknol dan Rekayasa). 2015;1.

12. Studener S. Combustion Engine Air Intake Theoretical Modelling, Model-Verfication \& Application to Optimal Valve Actuation. IFAC Proc Vol. 2012;45(2):171-6. DOI: https://doi.org/10.3182/20120215-3-AT-3016.00030

13. Obert EF. Internal Combustion Engines and Air Pollution. New York: Harper and Row Publisher; 1983.

14. Irawan B. Rancang Bangun Catalytric Converter dengan Material Substrat Tembaga (Cu) untuk Mereduksi Emisi Gas CO. Semarang; 2003.

15. Rymaniak Ł, Kamińska M, Szymlet N, Grzeszczyk R. Analysis of harmful exhaust gas concentrations in cloud behind a vehicle with a spark ignition engine. Energies. 
JEMMME (Journal of Energy, Mechanical, Material, and Manufacturing Engineering)

2021;14(6). DOI: https://doi.org/10.3390/en14061769

16. Karvounis E, Assanis DN. The effect of inlet flow distribution on catalytic conversion efficiency. Int J Heat Mass Transf. 1993 Jan;36(6):1495-504.

17. Schmack R, Friedrich A, Kondratenko E V., Polte J, Werwatz A, Kraehnert R. A meta-analysis of catalytic literature data reveals property-performance correlations for the OCM reaction. Nat Commun. 2019 Dec 25;10(1):441. DOI: https://doi.org/10.1038/s41467-019-08325-8 